\title{
EPIGRAFÍA Y PROPAGANDA ALMOHADES
}

\author{
MARÍA AnTONIA MarTíneZ NúÑ̃Z \\ Universidad de Málaga
}

La escritura árabe ha gozado siempre de un incomparable prestigio en el mundo islámico; una escritura impulsada por el movimiento expansivo del Islam al que había sido asociada desde el origen ${ }^{1}$. Y es que el primer rasgo característico que se percibe en los países islámicos es el lugar excepcional que ha ocupado en ellos desde siempre el signo gráfico, por lo que B. Messick habla de «dominio textual» y de «Estado caligráfico» para referirse a la sociedad islámica ${ }^{2}$. Sin duda, la razón hay que buscarla en la excelencia que el pensamiento filosófico del Islam ha otorgado a la escritura que anotaba la lengua de la revelación, permitiendo su conservación y facilitando su estudio y memorización, y de este hecho recibió una especie de «carácter sagrado».

Más significativo aún es el uso abundante de la prestigiosa grafía árabe como elemento ornamental, concretamente el lugar destacado que ocupa en tanto que «escritura de aparato» o «emblemática», como la denomina S. Gubert $^{3}$; un tipo de escritura dotada de solemnidad y con pretensiones estéticas, realizada en diversos lugares y sobre diferentes soportes, que constituye en el Islam el medio o la forma preferente de expresión del poder, y cuya finalidad es ser expuesta a los ojos de la comunidad, de los aliados y de los enemigos potenciales ${ }^{4}$.

Pues bien, una característica importante de esta grafía árabe, específicamente de la epigráfica, es el cambio que han experimentado a lo largo del tiempo el diseño de los grafemas y las técnicas de talla. Dicho cambio, iniciado e impulsado desde el poder en los epígrafes oficiales, se imitaba luego

\footnotetext{
1 Sobre las fases de evolución de la grafía árabe, cfr. Martínez Núñez, M. ${ }^{a}$ A., «Escritura árabe ornamental y epigragía andalusí», Arqueología y Territorio Medieval, 4 (1997), en prensa.

${ }^{2}$ Messick, B., The Calligraphic State. Textual Domination and History in a Muslim Society, Berkeley, Los Angeles, Oxford, 1993.

${ }^{3}$ Gubert, S., «Pouvoir sacré et pensée mystique: les écritures emblématiques merinides (VII $/$ XIII'-IX $/ \mathrm{XIV}^{\mathrm{e}}$ siècles)», Al-Qantara, XVII (1996), 391-497.

${ }^{4}$ Ibidem, 394-397.
} 
con más o menos fidelidad o intencionalidad en la epigrafía no oficial, realizada a expensas de particulares. Así, los rasgos específicos que presentan los caracteres gráficos, en su aspecto más estrictamente formal, permiten atribuir los diferentes epígrafes a determinados períodos cronológicos.

Si los rasgos puramente caligráficos adquieren en la epigrafía árabe un gran valor, el contenido textual de las inscripciones tiene asimismo una importancia incuestionable. Los epígrafes oficiales constituyen, a veces, los únicos testimonios conservados sobre algunas edificaciones, mientras que, en otras ocasiones, ratifican o matizan los datos aportados por los cronistas árabes sobre construcciones de diverso carácter. Por otra parte, estos textos, redactados en las cancillerías del Estado, ofrecen una abundante información sobre la concepción que dicho Estado tenía de sí mismo y sobre la forma en que quería que se le viese, y no sólo por los títulos protocolarios y de función que se consignan en gran número de epígrafes, sino también por las citas coránicas y las frases de alabanza que contienen; en última instancia, por la estructura general de los formularios, los cuales reflejan de múltiples formas las tendencias y orientaciones del poder constituido en un momento dado. En otras palabras, el poder establecido utilizaba y controlaba los textos y el diseño de los epígrafes oficiales con fines eminentemente propagandísticos.

La epigrafía árabe, junto a las monedas, constituye un documento directo y contemporáneo de la actividad desarrollada por la administración estatal y suministra una información que ha llegado hasta nosotros, casi siempre, $\sin$ las alteraciones ni las reelaboraciones a que pueden haberse visto sometidos los datos suministrados por otras fuentes escritas. Por consiguiente, la documentación epigráfica es adecuada, junto a otras, para comprender algunos aspectos relacionados con el poder y puede ser analizada desde diversos puntos de vista: el puramente caligráfico y el textual, pero también el tipo de soporte y el lugar de ubicación, pues influyen en el valor de su función propagandística.

La etapa de dominio almohade supuso para el Occidente islámico el cambio más sustancial en el terreno epigráfico. Por los datos que poseemos hasta el momento, el dominio almohade marcó la implantación oficial como grafía ornamental de la variante cursiva, más próxima a la escritura utilitaria y su legibilidad. Hasta ese momento el predominio del cúfico como grafía ornamental oficial había sido prácticamente absoluto.

Junto a eso, y aunque el cúfico dejó de gozar del uso exclusivo anterior, se siguió utilizando en época almohade y fue entonces cuando experimentó su evolución más espectacular, observándose un derroche en las complica- 
ciones formales de los grafemas, complementados con diversos motivos decorativos, como se detecta en los llamados «motivos-tipo» ${ }^{5}$, de gran fijeza, que se mantendrán en la epigrafía posterior. Con ello, se ampliaba el valor simbólico y propagandístico de este sistema gráfico, destinado a lo que se puede denominar como «interpretación colectiva», más que a una lectura individualizada.

Esas innovaciones y cambios experimentados por la epigrafía oficial respondían, sin duda, a las reformas llevadas a cabo por los almohades en varias fases y en diversos ámbitos, pretendiendo expresamente distanciarse de sus antecesores almorávides. Los medios de los que se valió el Mahdỉ Ibn Tümart para deslegitimar el poder almorávide y la forma en que los mu'miníes legitimaron su propia soberanía califal, son los que dan sentido a la necesidad de un potente sistema propagandístico, dirigido, en gran medida, a contrarrestar la propaganda almorávide anterior ${ }^{6}$, y que en el terreno de la epigrafía oficial se materializa fundamentalmente en la introducción de las innovaciones mencionadas, junto a otras que afectan al contenido de los epígrafes, como símbolos de identificación del poder almohade.

Si la existencia de sistemas y de medios propagandísticos no era un fenómeno nuevo en el mundo islámico, sí se acentuó en la etapa almohade con el desarrollo de una propaganda dinástica sumamente cuidada y diversificada: desde los cronistas y genealogistas «oficiales», la reorganización de la Kitāba y el uso de la 'alāma ${ }^{7}$ en los diplomas y la correspondencia oficial, la existencia de un rígido protocolo con un orden jerárquico establecido o la imposición en la estructura del sistema almohade de grupos dedicados especialmente a la propaganda: mubašsir/s, musammi ' $/ s, m u^{\prime} a d \underline{d} \underline{d i n} / \mathrm{s}^{8}$, etc., hasta las reformas monetarias, la monumentalidad de las mezquitas y de las puertas construidas o la producción de cerámicas con unas características especiales ${ }^{9}$. Todo un complejo sistema planificado desde el poder y en el que los textos epigráficos constituyen sólo uno de sus aspectos, pero de gran relevancia, por su cuidado diseño gráfico y por su léxico muy marcado y significativo.

\footnotetext{
${ }^{5}$ Ocaña Jiménez, M., Cúpulas de la mezquita de Tinmal: las inscripciones de sus celosías, en Ewert, C., y Wisshak, J. P., Forschunden zur almohadischen Moschee. Die Moschee von Tinmal (Marocco), Madrider Beiträge, 1984, 160-168.

" Cfr. Barbour, N., «La guerra psicológica de los almohades contra los almorávides», Boletín de la Asociación Española de Orientalistas, II (1966), 117-130.

${ }^{7}$ Lévi-Provençal, E., 'Alāma, ER', 1 (1960), 362-363.

8 Cfr. Lévi-Provençal, E., Documents inédits d'histoire almohade, fragments manuscrits du «legajo» 1919 du Fond Arabe de l'Escorial, Paris, 1928, 54 y 70-71.

9 Acién Almansa, M., «Cerámica y propaganda en época almohade», Arqueología Medieval, 4 (1996), 183-191.
} 
Por otra parte, y frente a lo que sucede en etapas anteriores, los epígrafes oficiales de época almohade no consignan ni el nombre del califa que ordena la construcción, ni el objeto de la fundación, ni la fecha de la misma, sino que contienen únicamente citas coránicas y eulogias y fórmulas de alabanza a Dios que se repiten una y otra vez.

Por ello, se ha hablado de «banalización» de la epigrafía y, por ejemplo, G. Deverdun, en su estudio sobre las inscripciones árabes de Marrakech, llega a afirmar: «Esperábamos pocas cosas de los almorávides y nada de los almohades, puesto que éstos no solamente y siempre manifestaron el alejamiento por las vanidades de este mundo, sino también se empeñaron en borrar, felizmente a veces bastante mal, todos los vestigios epigráficos de sus antepasados» ${ }^{10}$. Junto a su valiosa constatación de uno de los aspectos fundamentales de la política anti-almorávide llevada a cabo por los almohades, no deja de asombrar que, asumiendo el tópico del alejamiento de las vanidades mundanas, afirme que no esperaba nada de los almohades, cuando él mismo incluye entre las inscripciones almohades de Marrakech la banda en grafía cúfica de la monumental Bāb Agnaw y los epígrafes en cursiva de los mihrāăb/s de la Kutubiyya y de la mezquita de la Qașbah, y ninguno de ellos puede ser considerado como indicio o síntoma de dicho alejamiento.

Todo parece basarse en que no se consigna ni fecha explícita, ni el nombre de ningún soberano; esos datos son suministrados por otras fuentes, pero, como dijo J. Sauvaget, no existen inscripciones banales, hay solamente una manera banal de estudiarlas ${ }^{11}$, somos nosotros los que las estudiamos de una manera banal. $Y$ es que incluso las inscripciones que reproducen sólo versículos coránicos y eulogias suministran una información válida, por el lugar en que se ubican, por el tipo y diseño de la grafía utilizada o por las citas coránicas y el léxico elegidos. El hecho que Deverdun señala: martillear inscripciones almorávides de Marrakech o Tlemcén ${ }^{12}$ es significativo por sí mismo. Y es que Deverdun, como otros muchos autores, opina que sólo tienen valor histórico aquellos epígrafes que consignan datos concretos de carácter cronológico, toponímico, antroponímico, y así lo especifica cuando expone que su investigación estaba destinada ante todo a aportar datos históricos, por lo que «no hubiese debido publicar más que las inscripciones que encerraban un nombre o una fecha» ${ }^{13}$.

${ }^{10}$ Les Inscriptions arabes de Marrakech, Rabat, 1956, p. IX.

${ }^{11}$ Robert, L., Sciences auxiliaires traditionneles. Témoignages écrits. Epigraphie, en Samaran, Ch. (dir.), L'Histoire et ses méthodes, Paris, 1961, p. 471.

${ }_{12}$ Deverdun, Inscriptions arabes de Marrakech, 12-14.

13 Ibidem, IX-X. 
Sin embargo, otros epigrafistas no compartían ni comparten esa opinión, y así contamos con las valiosas aportaciones de M. Ocaña sobre los «motivostipo» de la mezquita de Tinmal y y sobre la epigrafía almohade de al-Andalus ${ }^{14} \mathrm{y}$ recientemente con el artículo de S. Gubert acerca del léxico utilizado en las «escrituras emblemáticas» meriníes ${ }^{15}$, donde demuestra que el análisis de dicho léxico remite a la ideología del poder meriní y a las bases de su legitimidad, pero no lleva a cabo el estudio caligráfico ni el de otros elementos que, como él señala (pp. 395 y 396), influyen en el valor de los epígrafes.

Por lo que se refiere a la epigrafía almohade, y como se desprende de los trabajos dedicados por M. Ocaña al tema, no se puede prescindir de dicho análisis caligráfico, pues es la forma misma que adquiere el diseño del cúfico o el uso ornamental de la grafía cursiva, junto al soporte y al lugar en que se ubican los epígrafes, lo que determina en primer lugar el valor propagandístico de estas escrituras. Este será el aspecto que abordaré, en primer lugar, para intentar después el análisis textual y sus implicaciones, centrando el estudio en las inscripciones monumentales y funerarias más significativas, así como en los epígrafes sobre cerámica, y recurriendo, cuando lo estime necesario, a la información suministrada por la numismática y otras fuentes escritas.

\section{CARACTERÍSTICAS DE LA EPIGRAFÍA ALMOHADE}

En general, son bastante escasos los restos andalusíes de segura cronología almohade que han llegado hasta nosotros, aunque sí contamos con algunos ejemplares que tipifican las nuevas orientaciones. Por dicha escasez, y porque el tema sobrepasa obviamente el ámbito andalusí, es preciso acudir a los restos de esa época - más abundantes y monumentales- que se conservan en el norte de África, especialmente en el Magreb al-Aqșà.

Como ya he mencionado, la transformación más importante de la escritura árabe ornamental bajo el impulso almohade consistió en la adopción oficial y la generalización del uso de los caracteres nasjíes, algo que había tenido ya lugar en Oriente, al ser utilizada la grafía cursiva por Nūr al-Din en las inscripciones oficiales de la Siria selyuquí ${ }^{16}$. Sin embargo, tanto en el

\footnotetext{
${ }_{14}$ Ocaña Jiménez, M., Cúpulas de la mezquita de Tinmal: las inscripciones de sus celosías, ya citado, y del mismo autor, «Panorama sobre el arte almohade en España», Cuadernos de la Alhambra, 26 (1990), 91-111.

${ }^{15}$ Gubert, «Pouvoir sacré et pensée mystique...», citado en nota 3.

${ }^{16}$ Ory, S., Kitäbät, II. Proche Orient, EF , V (1986), pp. 213-215; Sourdel Thomine, J., «Quelques étapes et perspectives de l'épigraphie arabe», Studia Islamica, 17 (1962), 5-22.
} 
Oriente como en el Occidente islámicos, existen precedentes escasos y puntuales en el uso de la cursiva que se adelantan a esa adopción oficial. Una de las muestras más antiguas del uso de la cursiva la proporcionan los epígrafes del mihrāab del Masŷid-i-Pa Manar ${ }^{17}$ en Zavara (Irán), del año 1068-69, a los que siguen otros ejemplares sirios: una inscripción de Busra del 1088 y muestras de la mezquita de Alepo del año $1090^{18}$.

De Oriente pasó a Ifrīqiya, de donde procede el epígrafe en cursiva más antiguo del Occidente musulmán: una estela funeraria datada en $1096^{19}$, y por esta vía oriental se difundió en el resto del Magreb, donde existen algunas muestras de grafía cursiva de etapa almorávide tardía: en la qubba almorávide de Marrakech, datada en el año 1120-21, en la mezquita de Tlemcen de 1135-36 y en la Qarawiyyin de Fez, también de la primera mitad del siglo XII ${ }^{20}$.

Por lo que se refiere a al-Andalus, la banda en grafía cursiva del Monte Mauror, en Granada, ha sido fechada en época almorávide ${ }^{21}$, y en Murcia, las inscripciones en cursiva de lo que se ha denominado como «estilo mardanīsí» ${ }^{22}$, han sido consideradas como almorávides, pero la mayor parte tienen una cronología más tardía, sobre todo almohade y hūdí. Dicho «estilo mardanī̌íi» ha sido definido como «nacional» frente al almohade, precursor de muchas invocaciones posteriores, y obra de los artesanos «Šarquíes», creadores de ese estilo.

Desde mi punto de vista ${ }^{23}$, es aventurado hablar de un estilo nacional y achacarlo a la iniciativa de los artesanos andalusíes, pues, aunque el intercambio de mano de obra a ambos lados del Estrecho y con otras zonas del

${ }_{17}$ Blair, Sh. S., The monumental inscriptions from early Islamic Iran and Transoxiana, Leiden-Nueva York, 1992, núm. 51, fig. 92.

${ }^{18}$ Ory, Kitāāāt, p. 215.

${ }^{19}$ Golvin, L., Kitäbät, IV. Afrique du Nord, El 2, V (1986), p. 218.

${ }^{20}$ Cfr. Deverdun, G., Etude épigraphique, en Meunié, J., y Terrasse, H., Nouvelles recherches archéologiques à Marrakech. La coupole almoravide de Marrakech, Paris, 1957, 49-53; Ocaña Jiménez, M., Kitābāt, EI V (1986), 216-217; Fernández Puertas, A., Calligraphy in al-Andalus, en Jayyusi, S. (ed.), The Legacy of Muslim Spain, Leiden-Nueva York-Köln, 1994, p. 651.

${ }_{21}$ Gómez Moreno, M., El arte español hasta los almohades. Arte mozárabe, Ars Hispaniae, III, Madrid, 1951, p. 264, fig. 317; Fernández Puertas, Calligraphy in al-Andalus, p. 653.

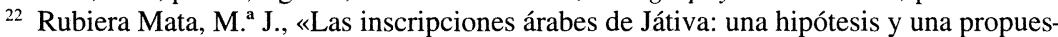
ta sobre la denominación de un estilo», Homenaje al profesor Darío Cabanelas Rodríguez $O$. F. M., con motivo de su LXX aniversario, Granada, 1987, 293-295; Navarro Palazón, J., Sharq al-Andalus. Resistencia frente a los almohades. (Con ocasión de la exposición de Murcia, 22XII-1993/31-I-1994), Murcia, 1993.

${ }^{23}$ Que he desarrollado en el artículo, de inminente publicación y citado anteriormente, «Escritura ornamental y epigrafía andalusí», al cual remito. 
mundo islámico hubo de ser intenso ${ }^{24}$, se olvida el control y la planificación ejercidos por el poder sobre estas producciones ${ }^{25} \mathrm{y}$ tampoco se tiene en cuenta la adopción de tendencias orientales, como ya se ha señalado en relación a la cerámica murciana ${ }^{26}$, ni la posibilidad de una actitud competitiva, pero también mimética, con respecto a la propaganda almohade, sobre todo teniendo en cuenta su cronología contemporánea o posterior a la misma.

$\mathrm{Y}$ es que, frente a la opinión tradicionalmente defendida, en el período comprendido entre los siglos XI y XIII existieron grandes analogías ${ }^{27}$ entre el Oriente y el Occidente islámicos: desde la inspiración en las grandes líneas del pensamiento islámico oriental hasta la creación de madrazas -institución conocida en Oriente desde el siglo XI-y las innovaciones arquitectónicas y decorativas, como la construcción de grandes puertas de aparato, el uso de muqarnas y las nuevas orientaciones en epigrafía.

Lo cierto es que el uso ornamental de la grafía cursiva se impuso y generalizó en el Magreb y al-Andalus a partir de la reunificación almohade. Ya Torres Balbás había señalado que los almohades, en cuanto a decoración arquitectónica, rompieron deliberadamente con los moldes de las etapas precedentes, establecieron una relación más estrecha entre al-Andalus y el norte de África, incluyendo ahora la Ifrīqiya impregnada de influencias orientales y egipcias, y desarrollaron en la arquitectura occidental y su decoración formas originarias de Oriente ${ }^{28}$; formas de inspiración oriental que fueron integradas en el programa almohade y readaptadas a sus necesidades.

La prueba más evidente de esa decisión oficial de imponer la grafía cursiva la proporcionan las acuñaciones monetarias de época almohade, pues junto a otras reformas significativas ${ }^{29}$, se utiliza dicha grafía de mane-

${ }^{24}$ Como afirma Ocaña Jiménez, «Panorama sobre el arte almohade en España», p. 91.

${ }_{25}$ Como expone Acién Almansa, M., Materiales e hipótesis para una interpretación del salón de 'Abd al-Rahmān al-Nașir, en Madinat al-Zahrā'. El salón de 'Abd al-Rahmān III, Córdoba, 1995, 185-186.

${ }^{26}$ Acién Almansa, «Cerámica y propaganda en época almohade», p. 184, donde se alude a los hūdíes, a su «programa pro-‘abbāsí» y a su legitimidad, conseguida a través del califa 'abbāsí, citando las aportaciones de Pierre Guichard, Julio Navarro y otros autores; cfr. p. 190, notas 6-10.

${ }^{27}$ Como exponen, por ejemplo, Sourdel, D. y J., La civilización clásica del Islam, trad. Sánchez Aleu, D., Barcelona, 1981, p. 124.

${ }^{28}$ Torres Balbás, L., «Arte almohade. Arte nazarí. Arte mudéjar», Ars Hispaniae, IV, Madrid, 1951, p. 10.

${ }^{29}$ Entre esas reformas estarían: la alteración del peso y el módulo, la desaparición de la fecha, el lugar de acuñación se cita pocas veces, el cuerpo principal de las leyendas se dedica a la mención del Mahdi y de los califas mu'miníes con su filiación, y sobre todo se adopta la forma 
ra sistemática, frente al uso prácticamente exclusivo del cúfico en etapas precedentes.

Pero no se trata sólo de las monedas. En al-Andalus son escasas las inscripciones de cronología almohade en grafía cursiva: una estela funeraria procedente de Córdoba del año 587/1191 y una mqābriyya de Mallorca fechada en años anteriores a la conquista cristiana de la isla en 1229, en las que se usan simultáneamente el cúfico y la cursiva ${ }^{30}$, igual que sucede en las hojas de la Puerta del Perdón de la catedral de Sevilla, enchapadas en metal y con carteles exagonales con epígrafes en cúfico, que reproducen al-mulk lillāh, y la aldaba con inscripción en cursiva ${ }^{31}$. Sin embargo, en Marrakech, la capital, sí se han conservado dos inscripciones emblemáticas: la del mihrāb de la Kutubiyya, fechada en el 553/1158, y la del mihrāb de la mezquita de la Qașbah, datada en el 584/1188 ${ }^{32}$. Ambas discurren por las cornisas sobre las que reposan las columnas de sostén del conjunto decorativo y están distribuidas en cinco paneles, correspondientes a las cinco caras del nicho. Realizadas en yeso, presentan los mismos caracteres cursivos, de muy buena factura, destacándose sobre un fondo decorado con motivos vegetales y amplias palmas lisas. Los caracteres del epígrafe de la Qașbah son más pequeños y ello permite que el texto reproducido - igual al de la Kutubiyya: basmala, tașliya declamatoria, ta 'awwud, Q. XXII, 76-77, y eulogia final, inspirada en Q. III, 89- sea aquí más completo.

La buena ejecución que presentan ${ }^{33}$ confirma el cuidado diseño y la planificación previa, pero también la influencia que puede tener el material uti-

cuadrada en las emisiones de plata, y en los dinares la leyenda central se enmarca en un cuadrado; cfr. Prieto y Vives, A., «La reforma numismática de los almohades», en Miscelánea de Estudios y Textos Árabes, Madrid, 1915, 11-114; Fontenla Ballesta, S., «La numismática almohade», I Jarique de Estudios Numismáticos Hispano-Arabes, Ponencias y Comunicaciones, Zaragoza, 1988, 67-88.

${ }^{30}$ La primera estela, con doble arco de herradura apuntado, contiene el epitafio de un sayj almohade y presenta el campo central en cúfico y la orla en cursiva; cfr. Lévi-Provençal, E., Inscriptions arabes d'Espagne, Leiden-Paris, 1931, núm. 28, pl. IXc. La mqābriyya se conserva en el Museo de Palma de Mallorca, carece de fecha y contiene el epitafio de una mujer en grafía cúfica en los lados ataludados y cursiva sin puntos diacríticos en los rectos; cfr. Roselló Bordoy, G., Corpus balear de epigrafía árabe, Palma de Mallorca, 1969, p. 27, núm. 15, lám. III y IV.

${ }^{31}$ Torres Balbás, Arte almohade..., p. 70, fig. 62; Salem, A., «La puerta del Perdón en la gran mezquita de la alcazaba almohade de Sevilla», Al-Andalus, XLIII (1978), 201-207.

${ }^{32}$ Deverdun, Inscriptions arabes de Marrakech, núm. 20, p. 14, y núm. 62, p. 53., respectivamente. La cronología de ambos epígrafes es la aportada por Deverdun a partir de otras fuentes escritas.

${ }^{33}$ Y que condujo a Deverdun a afirmar que no pudo ser obra más que de un artesano andalusí; ibidem, p. 30. 
lizado - en este caso el yeso que facilita la labor de los artesanos- en el resultado final. Y es que la diversificación de los materiales empleados - junto a la piedra, abundan ahora el yeso, la cerámica y la madera- constituye otro elemento que se debe añadir a los cambios introducidos en el terreno epigráfico. Así, la cerámica es el material utilizado en la admirable colección de brocales de pozo que se conserva en el palacio al-Badi` de Marrakech ${ }^{34}$. Presentan decoración estampillada y la mayor parte de ellos, vidriados en verde, motivos epigráficos en cursiva y en cúfico que reproducen breves eulogias. El mismo material y características semejantes aparecen, asimismo, en el brocal almohade que se conserva en Tetuán ${ }^{35} \mathrm{y}$ en otros de procedencia andalusíi ${ }^{36}$.

Aunque el cúfico no gozaba ya del uso exclusivo precedente, sí se siguió utilizando con frecuencia en la epigrafía almohade y, como ya ha quedado dicho, se vio dotado a partir de entonces de un nuevo diseño que, en consonancia con las orientaciones experimentadas ya por el cúfico oriental ${ }^{37}$, rompía con la tradición anterior. En general, el cúfico almohade se caracteriza por el desarrollo desmesurado en vertical de las astas o trazos altos de los grafemas, complementado en la parte inferior de la línea de base por pronunciados y abundantes nexos curvos. Es característico también que el cuerpo de cada uno de los grafemas adquiera una forma típica y específica que lo diferencia de las

${ }^{34}$ Ibidem, p. 11, núm. 17, bis.

${ }^{35}$ En grafía incisa y con la particularidad de contener la fecha: 1190 J. C.; cfr. Torres Balbás, Arte almohade..., p. 63, fig. 55 .

${ }^{36}$ Como los de Córdoba, uno con cuerda seca parcial, otro vidriado en verde; cfr. Exposición «La mezquita de Córdoba. Siglos VIII-XV», XII Centenario de la mezquita, Córdoba, 1986, núms.., fig. 127 y 128; los del Museo Arqueológico de Sevilla, vidriados en verde, con decoración estampillado o incisa y motivos epigráficos en cúfico y cursiva que reproducen $a l$ mulk, al-yumn (no al-mā'), al-sukr; cfr. Oliva, D.; Gálvez, E.; Valencia, R., «Fondos epigráficos árabes del Museo Arqueológico de Sevilla: brocales de pozo», II Congreso de Arqueología Nacional Española. Madrid, 19-24 de enero de 1987, III, Comunicaciones, Madrid, 1987, p. 80, núms. 3 y 4, lám. II, o los que han aparecido en Málaga, en una excavación de urgencia realizada en los primeros meses de 1997: uno de ellos está vidriado en verde y sólo conserva las astas de los grafemas de un epígrafe en cursiva, en el que puede leerse únicamente el inicio de la expresión al-'izz li-llāh, el otro está sin vidriar y presenta una banda inferior en grafía cúfica. Quiero agradecer a la arqueóloga responsable de la excavación el haberme facilitado el material gráfico para su estudio, que se encuentra en fase de realización.

37 Así, por ejemplo, las bandas epigráficas del miḩrāb de al-Afụal, en la mezquita de Ibn Țulūn en El Cairo, erigido en el año 1094, con motivos estereotipados y decoración geométrica y floral, muy parecidas a las sirias contemporáneas, o los frisos de la madraza Haydariyya de Qazwin, de los siglos XI-XII; cfr. Sourdel, La civilización clásica del Islam, p. 186, núm. 60, y p. 240, núm. 65, o los epígrafes de la mezquita al-'Abbās al-Asnāf, en Hawlan (Yemen), datados en el 519/1125; cfr. Coussonet, N., y Ory, S., «Les inscriptions de la mosquée de Dī Bīn au Yémen», Les Cahiers du Centre Français d'Etudes Yéménites, 1 (1996), 32-34. 
restantes figuras y que se mantendrá prácticamente inalterable en la epigrafía posterior ${ }^{38}$. En ese diseño típico es de destacar el equilibrio alcanzado por la combinación de trazos curvos y rectos, y por la orientación horizontal, vertical y oblicua de los mismos, a lo que se añade la prolongación ascendente, a veces con complicados quiebros y enlaces con otras figuras, de algunos grafemas, como el 10f y a $\left(f \bar{a}^{\prime}, q \bar{a} f\right)$, 14f y a $(n \bar{u} n)$ y $17 \mathrm{f}$ a $\left(y \bar{a}^{\prime}\right)$. Como innovación más relevante, hay que señalar las complicaciones ornamentales - tanto vegetales como geométricas - que adquieren las astas de algunos grafemas, fundamentalmente el 1 (alif) y el 12 (lām) todas sus posiciones, pero también el $8\left(t \bar{a}^{\prime}, z \bar{a}^{\prime}\right)$ o el $14 \mathrm{f}$ y a $(n \bar{u} n)$. En cuanto a las prolongaciones geométricas, se produce el retorno en escuadra, formando a veces un nudo entrecruzado en la parte superior, y el quiebro en oblicuo del trazo vertical, lo que se acentuará en el cúfico nazarí y meriní. Junto a todo ello, se utilizan a veces estilizaciones vegetales y florales de relleno o de fondo.

Esa grafía cúfica es la que presentan las inscripciones almohades de alAndalus. Como se ha adelantado, se trata de un escaso número de epígrafes, en su mayor parte de carácter funerario. De Málaga procede el ejemplar más representativo de segura cronología almohade: una mqābriyya de mármol blanco que contiene el epitafio de Maryām, hija de Abū Ŷa 'far ibn 'Abd alGanī, fallecida en el 618/1221, por tanto, bastante tardía. Está realizada en caracteres cúficos típicamente almohades (lám. 1, fig. 1), que discurren sobre un fondo con decoración vegetal y cuyas astas terminan asimismo en ornamentos vegetales, con la particularidad de presentar un orificio circular en el centro, lo que le confiere un aspecto próximo a los motivos zoomórficos. M. Ocaña dedicó dos artículos ${ }^{39}$ a estudiar en detalle esta mqābriyya, a los cuales remito.

También en Málaga, en unas excavaciones de urgencia llevadas a cabo entre los meses de enero y marzo de 1991, apareció una mqābriyya única hasta el momento en al-Andalus ${ }^{40}$. Se encontró fragmentada - conserva

\footnotetext{
${ }^{38}$ Sobre estas características, cfr. Fernández Puertas, A., «Dos lápidas almohades. Mqābrīya de Játiva y lápida de la cerca de Jerez de la Frontera», Miscelánea de Estudios Árabes y Hebraicos, XXVII-XXVIII, 1 (1978-79), 226-228 y 229-231, figs. 2 y 4.

39 Ocaña Jiménez, M., «Una mqābriyya almohade malagueña del año 1221 J. C.», y «Nuevos datos sobre la mqābriyya almohade del año 1221 J. C.», Al-Andalus, XI (1946), 224-230 y 445-446, respectivamente. Cfr. también Acién Almansa, M. y Martínez Núñez, M. ${ }^{2}$ A., Catálogo de las inscripciones árabes del Museo de Málaga, Madrid, 1982, núm. 22, lám. XXVII.

${ }^{40}$ Fernández Guirado, I., «Informe arqueológico del sondeo realizado en calle Agua, núm. 16 (Málaga)», Anuario Arqueológico de Andalucía, 1991, III. Actividades de urgencia, pp. 319-325, incluye descripción del enterramiento y de la mqābriyya, pp. 320 y 324 , y de la misma autora, $L a$ necrópolis musulmana de Ŷabal Farūh (Málaga). Nuevas aportaciones, en Torres Palomo, M. ${ }^{a}$ P., y Acién Almansa, M. (eds.), Estudios sobre cementerios islámicos andalusíes, Málaga, 1995, $37-$ 68, descripción enterramiento, p. 46, reproducción fotográfica del mismo, figura 5.
} 


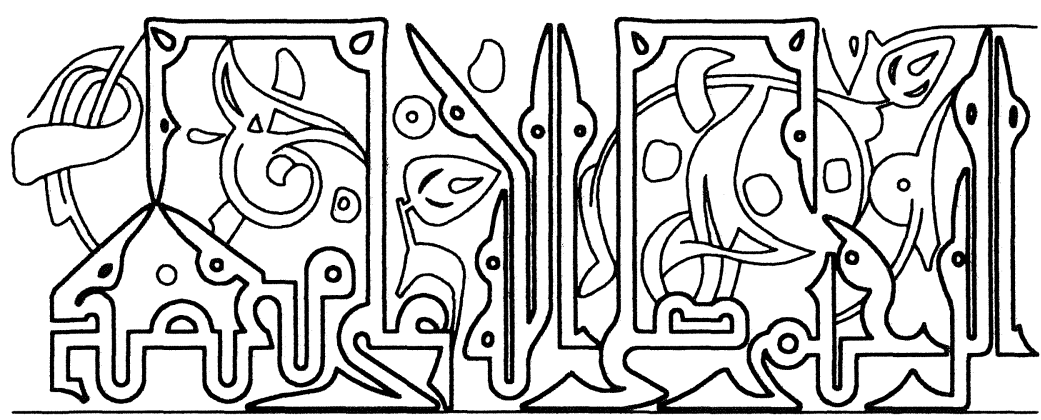

Fig.1

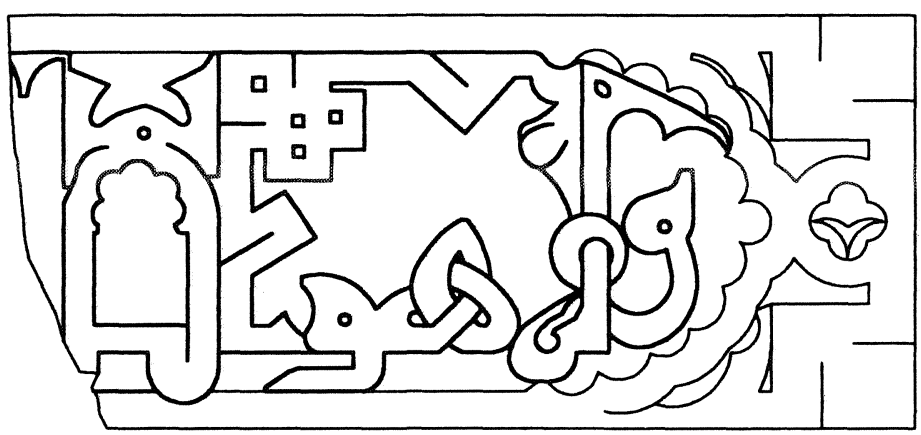

Fig. 2

LÁM. 1: Grafía cúfica de la Mqābriyya del Museo de Málaga (618/1221) y de la inscripción del castillo de Loja.

sólo la parte correspondiente a uno de los extremos, con unos $40 \mathrm{cms}$. de largo, 19 de ancho y 13 de altura- y ubicada sobre un pequeño plinto estucado en ocre. Una hilada de ladrillos hincados de canto en la tierra, con la parte visible vidriada en verde, delimitaba el perímetro de la sepultura. La mqābriyya, con doble moldura en su base, es de cerámica vidriada en verde, se enmarca en trazos de lacería y presenta en los lados triangulares decoración vegetal y en los trapezoides epígrafes en cúfico que se reducen a las expresiones: al-baraka wa-l-`...(li-llāhh) y al-gibța al-muttașila li-lläh. Los caracteres cúficos (lám. 2), complementados con estilizaciones vegetales de relleno, presentan el típico diseño almohade y los trazos altos de las figuras $1 \mathrm{i}, 12 \mathrm{i}$ y $\mathrm{m}, 8 \mathrm{~m}$ y $11 \mathrm{i}(k \bar{a} f)$ tienen también el característico retorno en escuadra y el $12 \mathrm{~m}$ un quiebro oblicuo en curva. Las astas terminan generalmente 
en bisel y siempre presentan el orifico circular en el extremo, como la mqābriyya de 1221.

Este ejemplar demuestra que en época almohade empezó a utilizarse la cerámica como material funerario, novedad que se afianzará en la etapa nazarí, y confirma que en ese momento tuvo su origen la disociación que se observa en los textos funerarios posteriores: por un lado, largos epitafios con ampliación de los formularios, como en la estela de Córdoba de 567 H, y simples eulogias o breves textos coránicos, por otro, sin que se puedan adjudicar unos a clases sociales poderosas y a clases bajas estos últimos, pues presentan una ejecución muy cuidada y una rica decoración.

Lo anterior queda ratificado a través de otra mqābriyya de mármol blanco, aparecida en Játiva y que ha sido fechada a finales del siglo XII ${ }^{41}$. El campo epigráfico se enmarca también en lacería, y sus trazas cúficas corresponden a las características ya descritas, aunque menos evolucionadas, y discurren sobre un fondo liso con algunas estilizaciones vegetales de relleno. El texto reproduce la fórmula profiláctica del $t a^{c} a w w u d$, basmala, tașliya, Q. XXVIII, 88, y una eulogia de inspiración coránica (Q. III, 89), como en los mihrāb/s de Marrakech.

Se podrían citar otros epígrafes funerarios andalusíes, pero ello alargaría en demasía esta exposición, por lo que sólo creo oportuno señalar que, en cuanto a los soportes, los almohades siguieron utilizando simultáneamente el tipo mqābriyya y el de estela rectangular, con arcos inscritos y sin ellos ${ }^{42}$.

Aparte de los epígrafes funerarios, pocos son los restos andalusíes de época almohade que se nos han conservado. En la alcazaba de Málaga se conservan dos inscripciones en cúfico sobre sendos collarinos de las columnas de mármol que dan acceso a la torre de Maldonado. Gran parte de los caracteres cúficos, sobre fondo liso, tienen el diseño típico almohade, mientras que otros presentan un aspecto más arcaizante, por lo que se les ha dado una cronología de la segunda mitad del siglo XII ${ }^{43}$. Reproducen citas coránicas: Q. XXVII, 26, y Q. XLII, 8, respectivamente. En el primer tercio del siglo XIII ha sido datada la lápida de la cerca de Jerez de la Frontera ${ }^{44}$, cuyo texto se compone de basmala, tașliya y última parte de Q. XII, 64. Está

${ }^{41}$ Fernández Puertas, «Dos lápidas almohades...», p. 225.

${ }^{42}$ Para una visión global de las estelas funerarias almohades, cfr. Martínez Núñez, «La estela funeraria en el mundo andalusí», 435-438, y Lévi-Provençal, Inscriptions arabes d'Espagne, núm. 48, pl. XIIc (epitafio pacense de un faqìh).

${ }_{43}$ Acién Almansa y Martínez Núñez, Catálogo de las inscripciones árabes del Museo de Málaga, núms. 20 y 21, lám. XXV y XXVI, pp. 10-11 y 15.

${ }^{44}$ Fernández Puertas, «Dos lápidas almohades...», p. 228. 


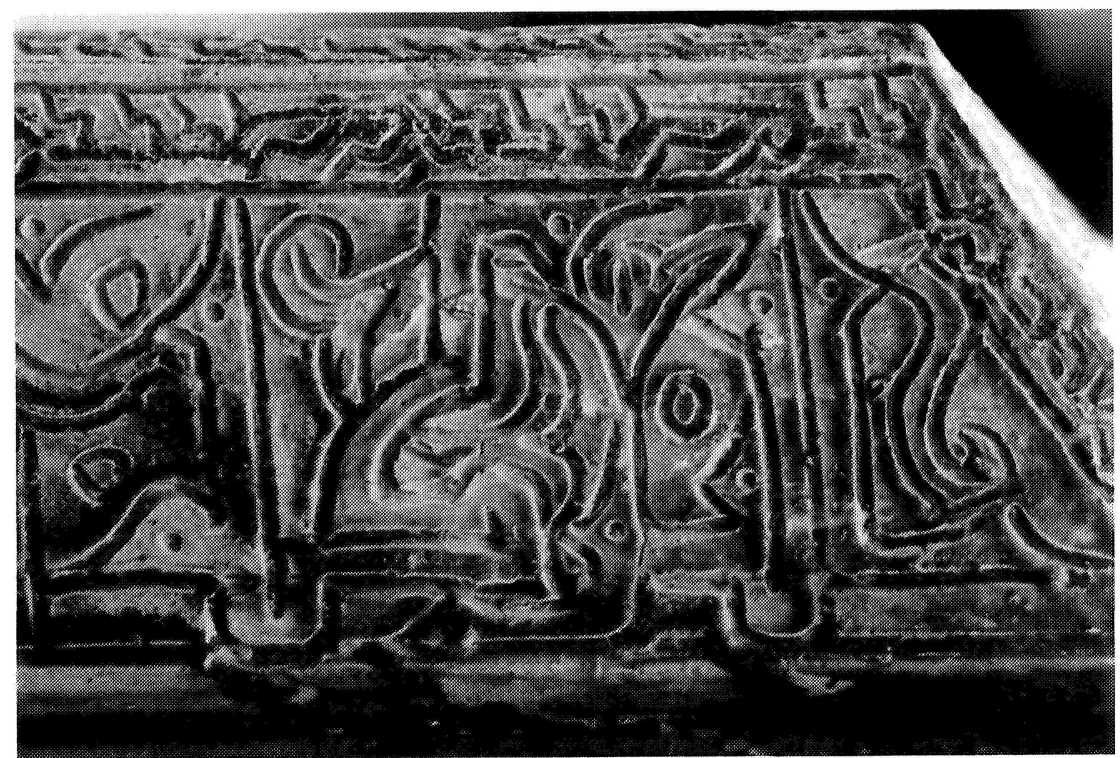

LÁM. 2: Mqābriỵya de cerámica vidriada en verde. Excavaciones de urgencia (Málaga, 1991).

realizada también en cúfico sobre fondo liso, pero con un gran desarrollo geométrico en los trazos altos —a base de cintas y complicados entrelazos-, lo que supone el inicio de lo que será después el cúfico nazarí y meriní. El mismo cúfico geométrico sobre fondo desnudo (lám. 1, fig. 2) se aprecia en la inscripción, tallada en piedra y de grandes proporciones, del castillo de Loja (Granada), cuyo texto reproduce la sūra coránica CXII, sobre la unidad de Allāh. El material y el texto utilizados, junto a sus rasgos epigráficos, en los que destaca la profusión de complicaciones ornamentales geométricas y vegetales de los trazos altos, podrían situarla cronológicamente en los últimos años del dominio almohade, por lo que no creo que pueda otorgársele una cronología nazarí, como se ha hecho en un «avance informativo» de reciente publicación ${ }^{45}$, y donde se ofrece una traducción parcial del epígrafe.

${ }^{45}$ Sánchez Martínez, J. A., et alii, «Reencuentro con Medina Lawša. Un proyecto de arqueología medieval en Loja», Revista de Arqueología, 170 (junio de 1995), 42-47. Muy problemática resulta, sin embargo, la cronología almohade que se ha otorgado al Cuarto Real de Santo Domingo (Granada), aunque en otras ocasiones se ha fechado en los inicios de la etapa nazarí, y a la mezquita de Fiñana (Almería), especialmente por la profusa decoración de su mihrāab, aspecto que he recogido en el artículo «Escritura ornamental y epigrafía andalusí», ya citado, al cual remito. 
Como en el caso de la grafía cursiva, en Marruecos se han conservado lógicamente las mejores muestras del cúfico oficial almohade. En primer lugar, hay que destacar la aparición de los llamados «motivos-tipo», estudiados por M. Ocaña en su manifestación más antigua y relevante: los epígrafes de la mezquita de Tinmal. Dicha mezquita, la primera fundada por el califa 'Abd al-Mu'min en el año 549/1154, presenta la austeridad que tantas veces se ha señalado con respecto a las construcciones religiosas almohades ${ }^{46}$. Sin embargo, existen dos elementos que matizan lo anterior: el entrelazado geométrico que enmarca la portada del mihrāb, reproducción ${ }^{47}$ del empleado en el caravasar Ribat-i-Malik (Uzbekistan) ${ }^{48}$ del año 471/1078-79, y las celosías de las cúpulas que cubren la nave de antesala al mihrāb, cuyos epígrafes reproducen frases de alabanza a Dios, escritas en cúfico y caracterizadas por una exuberante ornamentación vegetal de fondo y por el entrelazado en dos niveles de los términos que las componen. Estos motivos epigráficos tienen como base de diseño la palabra Allāh o la expresión $l i$ lläh, que se sitúan en la parte inferior del campo epigráfico, con una gran prolongación en horizontal de los nexos, de tal manera que puede contener al segundo término en el nivel superior y permite entrecruzar los nexos curvos del mismo. La novedad más importante es la prolongación en vertical de las astas, lo que permite entrecruzarlos y formar cadenetas simples o arcos polilobulados, junto a la simetría conseguida al enfrentar el mismo motivo epigráfico, pero escrito en sentido inverso ${ }^{49}$. Estos motivos-tipo, de gran fuerza decorativa, tuvieron una enorme fijeza posterior, pues fueron reproducidos por los artesanos mudéjares, degenerándose después ${ }^{50}$, y se incorporaron a la ornamentación de los palacios nazaríes y de las construcciones meriníes.

Las composiciones epigráficas que ostenta una de las cúpulas de mocárabes de la mezquita al-Qarawiyyin de Fez, atribuidas a la etapa almorávide, responden al mismo diseño que las de Tinmal, por lo que M. Ocaña las adjudicó a una intervención llevada a cabo por los almohades en dicha cúpu$\mathrm{la}^{51}$. Y de hecho, se sabe que el cuarto califa, al-Nāșir (595-613/1199-1213), ordenó la remodelación de dicha mezquita.

46 Torres Balbás, Arte almohade..., p. 10; Ocaña Jiménez, «Panorama del arte almohade en España», pp. 91-92.

${ }^{47}$ Hoag, J. D., Arquitectura islámica, trad. Novella Domingo, J., Madrid, 1976, p. 108.

48 Blair, The monumental inscriptions from early Iran..., p. 259, núm. 58, fig. 102.

49 Ocaña Jiménez, Cúpulas de Tinmal..., pp. 161-163, figs. 1-5, taf., 72-73.

50 Ibidem, taf. 80 d.; Torres Balbás, Arte almohade..., pp. 237 y ss.

51 Ocaña Jiménez, Cúpulas de Tinmal..., p. 162, taf. 80 b, c. 
Si la profusión ornamental estaba limitada en las mezquitas, sobre todo en el propio mihrāb, no ocurre lo mismo con las construcciones de otro carácter, en las que se inicia la tendencia, que triunfará plenamente en la arquitectura nazarí y meriní, a enmascarar la estructura de los edificios con enchapados y revestidos decorativos. No obstante, en las edificaciones almohades los tres grandes temas ornamentales: ataurique, entrelazo - todavía pobres, pero de creciente importancia - y epigrafía, aparecen casi siempre independientes o en combinaciones de decoración vegetal y epigráfica o ésta con la geométrica.

Buena prueba de esta tendencia la constituyen las puertas monumentales de Rabat y Marrakech, ricamente decoradas, a pesar de la dificultad del material utilizado: la piedra. Estas puertas, sin resonancia en la península al menos durante el período almohade, rompen con el carácter utilitario de las obras militares del Islam occidental y constituyen «verdaderos arcos triunfales» ${ }^{52}$ levantados en honor de la dinastía. Las puertas de los siglos siguientes son una reproducción de las almohades, como la de la Chellah de Rabat, o están inspiradas en ellas ${ }^{53}$.

Dos son las puertas de Rabat destacables desde el punto de vista epigráfico: la gran puerta de la Qașbah de los Ūdāya, construida en 1194 por el tercer califa almohade Abū Yūsuf Ya 'qūb al-Manșūr, y la Bāb al-Ruwāḥ, la mayor de la cerca almohade de Rabat, cuya construcción ha sido fechada también antes de finalizar el siglo XII ${ }^{54}$. La puerta de la Qaṣbah de los Ūdāya presenta decoración de ataurique en las albanegas del arco y epígrafes, tanto en la fachada exterior, más deteriorada, como en la interior. El plan decorativo de ambos conjuntos parece idéntico: una banda epigráfica en tres paneles, cuyo texto reproduce ta 'awwud, basmala, tașliya y Q. LXI, 11-3, bordeando el arco, en un cúfico muy cuidado sobre fondo desnudo, salvo algunas estilizaciones vegetales entre las astas de los grafemas (lám. 3, fig. 1), y un friso de arcadas ciegas que sobremonta el conjunto y forma la última parte de la composición ${ }^{55}$. Este friso se compone de una sucesión de motivos-tipo repetidos, que reproducen tres eulogias diferentes (lám. 4) y son semejantes a los de Tinmal, pero con la acentuación ahora de los entrelazados

${ }^{52}$ Torres Balbás, Arte almohade..., p. 11; Caillé, J., La ville de Rabat jusqu'au Protectorat français, I. Histoire et Archéologie, Paris, 1949, 99-100.

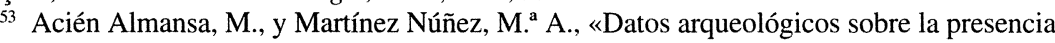
meriní en Málaga» Actes du Colloque Fès et al-Andalus, Fez, 29-30 de noviembre de 1995 (en prensa).

${ }_{54}$ Caillé, La ville de Rabat..., 96-110 y 139-144, respectivamente.

55 Ibidem, figs. 23-25. 


\section{9e.5.}

Fig.1

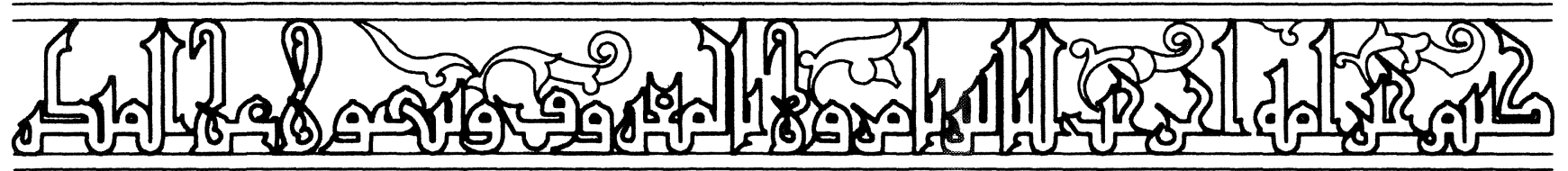

Fig. 2

LÁm. 3: Cúfico de las bandas epigráficas de la puerta de la Qașbah de los Ūdāya y de la Bab Ruwāḥ (finales siglo XII) en Rabat. 


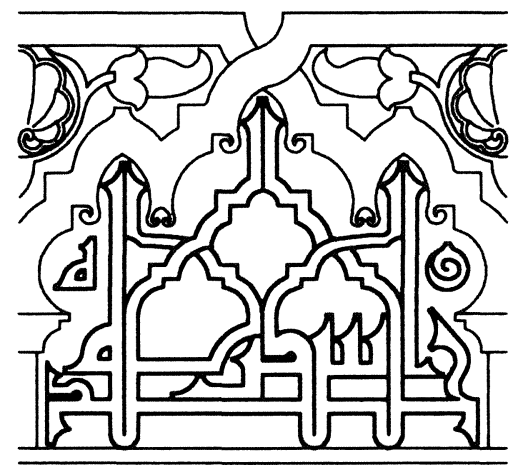

Fig. 1

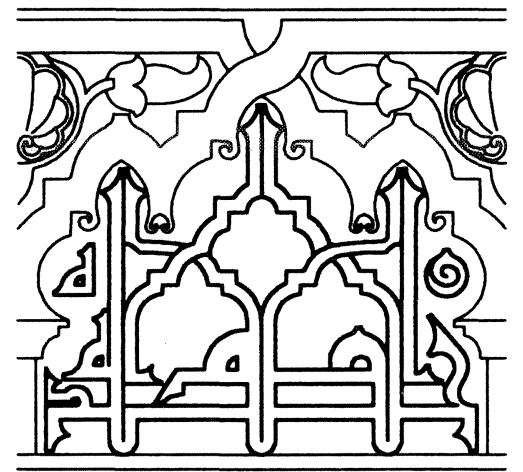

Fig. 2

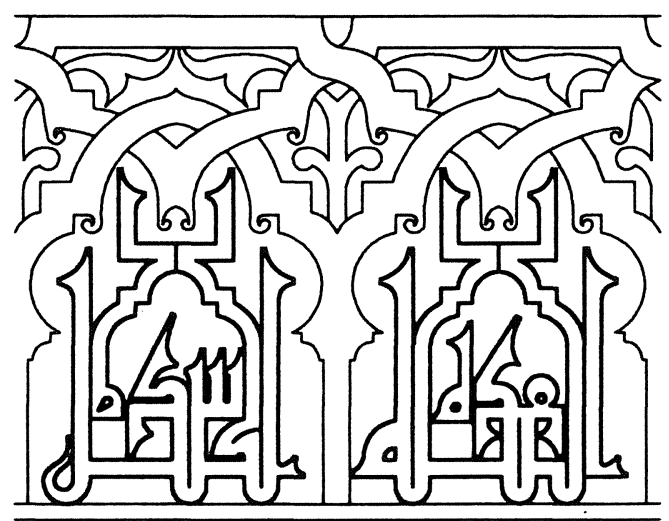

Fig.3

LÁM. 4: Motivos-tipo de la puerta de la Qaṣbah de los Ūdāya. 
geométricos de las astas y la separación por unas columnillas, cuyas prolongaciones se entrelazan en complicadas figuras. Hay que señalar la forma curvilínea en espiral que adquiere el $w \bar{a} w$ en posición aislada, también en la banda epigráfica, y su ubicación en la parte superior derecha del motivo (lám. 4, figs. 1 y 2), en simetría con el trazo 15f, con el objetivo de otorgar a ese trazo 16a un valor decorativo del que carece en su diseño original, como señaló M. Ocaña sobre los motivos de Tinmal (p. 164).

La Bāb al-Ruwāḥ es, entre las cinco puertas de la muralla almohade de Rabat, la más decorada y la única que contiene epígrafes. Su ornamentación, semejante a la anterior, recubre enteramente el panel central de la cara exterior, en la que destaca la banda epigráfica (lám. 3, fig. 2) en tres paneles, en buen estado de conservación, y con dos medallones para marcar el inicio y el final de la misma. La inscripción, realizada en el tipo de cúfico de la de los Ūdāya, pero con retornos en escuadra de los trazos altos más abundantes, reproduce las mismas fórmulas introductorias, seguidas de Q. III, 106-107. Breves eulogias en cursiva - perdidas hoy en su mayor parte - se diseminan por los sillares, entre otros elementos decorativos ${ }^{56}$.

Las bandas en cúfico de estas puertas muestran un gran afán de simetría, y en ellas los propios grafemas son suficientes para dar impresión de decoración, por lo que los elementos vegetales de relleno, florones y palmas simples o dobles, ocupan un lugar bastante restringido. Idénticas características decorativas y epigráficas presenta la Bāb Agnaw de Marrakech ${ }^{57}$, construida también por el califa Ya'qūb al-Manșūr en el año 584/1188, y cuyo texto reproduce las mismas fórmulas introductorias, seguidas, en este caso, de Q. XV, 46-48.

En la capital, Marrakech, se conservan otras inscripciones en cúfico, como las cortas eulogias que presenta el alminar de la Kutubiyya ${ }^{58}$, cuya decoración exterior se completa con un revestimiento en cerámica vidriada en blanco sobre fondo azul, y la inscripción coránica que se ubicaba en el alminar de la mezquita de la Qașbah ${ }^{59}$. De esta última se conservan algunos fragmentos con escritura cúfica de grandes dimensiones, muy próxima a la de Bāb Agnaw, que reproducían ta 'awwud, basmala y fătiha. La inscripción, realizada en cerámica del tipo de «cuerda seca», se destacaba en violeta oscuro sobre fondo blanco y constituía la banda superior de la decoración en

56 Ibidem, figs. 45 y 49

57 Deverdun, Inscriptions arabes de Marrakech, 49-50; Allain, Ch., y Deverdun, G., «Les portes anciennes de Marrakech», Hespéris, XLIV (1957), 82-126.

${ }^{58}$ Deverdun, Inscriptions arabes de Marrakech, p. 15, núm. 20, bis.

59 Ibidem, 54-55, núm. 64. 
cerámica del minarete. El uso de la cerámica en la decoración arquitectónica procede de Oriente, Persia y Mesopotamia, donde contaba ya con una remota tradición. El alminar de la Kutubiyya es el ejemplar más antiguo en el Occidente islámico de este tipo de decoración exterior.

De influencia oriental ha sido considerada también la 'anāza (mihrāa auxiliar de madera) de la mezquita de los andaluces de Fez (604/1207), forma de mihrāb atestiguada en el Egipto fātimí desde el siglo X, y asimismo su decoración, con arcos «recticurvilíneos» y grafía cúfica semejante a la de las grandes puertas almohades ${ }^{60}$. Características semejantes presenta el minbar de madera ${ }^{61}$ de la misma mezquita, ejecutado entre el 600-610/12031213, cuya inscripción cúfica contiene la taṣliya, seguida de Q. XXXIII, 70-71 y 56, y un friso de madera fechado en las primeras décadas del siglo XIII, que reproduce Q. XXXIII, 42. Su grafía cúfica es comparada no sólo con la de las puertas almohades, sino con la de una mqābriyya de $\mathrm{Fez}^{62}$, en mármol blanco, del año 611/1214, la cual se asemeja, aunque su ornamentación de relleno sea más escasa, a la malagueña de 1221. De todo ello se infiere la uniformidad de las directrices oficiales en materia epigráfica y su difusión por al-Andalus y el Norte de África y que las relaciones entre el Magreb extremo y el Oriente islámico seguían siendo intensas.

Por otra parte, la edilicia oficial almohade de Marruecos atestigua un potente programa constructivo, atribuible a ' $\mathrm{Abd}$ al-Mu'min, pero sobre todo a Ya'qūb al-Manșūr y, en menor medida, a su sucesor Muḥammad al-Nāṣir, con la remodelación de la Qarawiyyinn y la construcción de la Bāb al-Šarī $\varsigma^{\prime} a$ y de un burŷ, también en Fez. En efecto, en la etapa de Ya'qūb al-Manșūr, el califa que introdujo también algunas innovaciones en la acuñación de moneda ${ }^{63}$, se construyeron las grandes puertas de Rabat y Marrakech, los alminares de la Giralda (acabada de construir en 1195) y la colosal Tour Hassan de Rabat, la mezquita y el alminar de la Qașbah de Marrakech o la mezquita Bū Ŷlūd de la Qaṣbah de Fez. Todos estos edificios están, como afirma P. Guichard ${ }^{64}$, estrechamente asociados a la grandeza y al prestigio

${ }^{60}$ Cambazard Amahan, C., Le décor sur bois dans l'architecture de Fès. Epoque almoravide, almohade et début merinide, Paris, 1989, p. 104.

61 Ibidem, 121 y 210-211.

62 Ibidem, 118-119, pl. XXVIII: A, para el friso, y 121-122, pl. XXVIII: B, para la maābriyya.

${ }^{63}$ Con la acuñación de las famosas doblas, dinares de doble peso, y la utilización por primera vez en las leyendas del lema almohade: al-hamdu li-llāh wahdu-hu; cfr. Prieto y Vives, $L a$ reforma numismática de los almohades, 24 y 26.

${ }^{64}$ Guichard, P., Les Etats musulmans du Maghreb, en Gabrieli, F. et alii, Maghreb Médieval. L'apogée de la civilisation islamique dans l'Occident arabe, Aix-en-Provence, 1991, p. 193. 
de la línea dinástica que 'Abd al-Mu'min hizo prevalecer frente al resto de clanes y dignatarios almohades, en un momento en el que el proyecto mu’miní se encontraba prácticamente realizado y en su período más brillante ${ }^{65}$. La monumentalidad de estas construcciones, sin parangón en etapas precedentes del Occidente islámico, era en sí misma el mejor medio propagandístico de la dinastía.

Pero tal vez debido, entre otras causas, a esa monumentalidad, y en contraste con los textos fundacionales y conmemorativos de los califas y soberanos precedentes, la epigrafía oficial del califato almohade no tiene ni ese carácter fundacional, ni el propiciatorio para el califa tan típico de los formularios usados por 'abbāsíes, fātimíes y omeyas de al-Andalus ${ }^{66}$. Los textos de los epígrafes almohades son de carácter eminentemente religioso, pero no por ello intrascendentes o irrelevantes.

\section{Contenido textual de los epígrafes}

El formulario de las inscripciones oficiales almohades, e incluso de algunos epígrafes funerarios, empieza siempre con una serie de fórmulas introductorias, seguidas de una o varias citas coránicas, finalizando, a veces, con una frase piadosa o de inspiración coránica. Junto a eso, eulogias y expresiones de alabanza al Dios único se repiten sin cesar en todo tipo de lugares y soportes.

No se puede negar que este hecho nos priva de conocer los datos que la epigrafía fundacional de las etapas precedentes proporcionaba sobre títulos protocolarios y de función, fechas concretas de terminación de las obras, nombres de los directores de las mismas o de los artesanos que intervinieron en su realización. Y aunque algunos de ellos puedan suplirse, en parte, gracias a la valiosa información que aportan otras fuentes documentales, lo que sorprende es constatar cómo en los textos epigráficos se evita toda mención, mientras que en las leyendas de las monedas, por ejemplo, se cita expresamente no sólo al Mahdī y al califa con sus títulos máximos y filiación, sino a aquéllos que le precedieron también con sus títulos, aunque se omita siempre la fecha de acuñación.

${ }^{65}$ Ferhat, H., Le Maghreb aux XII et XIII siècles: les siècles de la foi, Casablanca, 1993, 91-99.

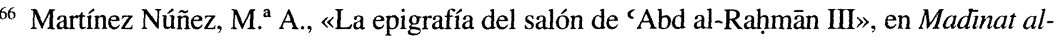
Zahrā. El Salón de 'Abd al-Rahmān III, Córdoba, 1995, 107-152. 
En el caso de la epigrafía, y como ya se ha mencionado, tanto los soportes, que permiten un mayor desarrollo y una mejor ejecución de los cambios gráficos y decorativos diseñados como signos distintivos del poder, como la monumentalidad de los lugares de ubicación, son en sí mismos los mejores medios propagandísticos de la dinastía. Pero, aparte de eso, la diferencia entre los textos epigráficos y las leyendas de las monedas tal vez pueda explicarse también por el hecho de que la no inclusión del nombre del califa en las acuñaciones, así como el omitir su mención en la juṭa, hubiese indicado, de hecho, renunciar al título califal, pues ambas eran prerrogativas soberanas. En otras palabras, las inscripciones de las monedas, por sus especiales características, y a pesar de las reformas introducidas por los nuevos califas, estaban sujetas a pautas generales prefijadas, mientras que los epígrafes monumentales permitían marcar de forma más decidida la especificidad con la que los mu'miníes deseaban presentarse.

Sea como fuere, lo cierto es que los textos de la epigrafía oficial almohade presentan la particularidad de ser exclusivamente religiosos y que este mismo hecho supuso un cambio drástico y expresamente buscado con respecto a la epigrafía oficial anterior; cambio que se concreta en la utilización de fórmulas introductorias fijas y de citas coránicas concretas, junto a un léxico repetitivo indisociable del registro religioso, todos los cuales remiten a las bases sobre las que se asienta la legitimidad mu’miní.

Con respecto a las fórmulas introductorias, se reducen a tres: $t a^{\complement} a w w u d$, basmala y tașliya, que están presentes en todos los epígrafes monumentales de Marruecos, con ciertas variantes y alterando el orden en ciertas ocasiones. Así, en los mihräb/s de las dos mezquitas de Marrakech aparece primero la basmala, seguida de tașliya y ta'awwud, mientras que en las puertas monumentales de Rabat y Marrakech es el $t a^{\top} a w w u \underline{d}$ el que se ubica en primer lugar. En al-Andalus, el $t a^{\top} a w w u \underline{d}$ está ausente de la lápida de la Cerca de Jerez y la inscripción del castillo de Loja carece de fórmulas introductorias.

La innovación con respecto a la epigrafía anterior se refiere fundamentalmente a la ampliación del uso del $t a^{\top} a w w u d$, fórmula profiláctica consistente en la expresión $A^{\complement} \bar{u}$ dé bi-llāh (al-'ažìm, ampliación en la Bāb Agnaw) min alS̆aytān al-raŷ̃m, que se utiliza antes de recitar cualquier versículo coránico, según recomendación expresa del Corán (Q. XVI, 100). El ta`awwud está documentado ya en época almorávide, pero sólo en epígrafes funerarios y como fórmula secundaria, ubicada generalmente en la orla de las estelas ${ }^{67}$. Los al-

${ }^{67}$ Martínez Núñez, M. ${ }^{\text {a }}$ A., «Estelas funerarias de época almorávide aparecidas en Córdoba», Miscelánea de Estudios Árabes y Hebraicos, 45 (1996), núm. 1, 135-136. 
mohades la incluyen dentro de las fórmulas introductorias, con frecuencia iniciando el texto, y la utilizan por primera vez en inscripciones monumentales de todo tipo, como mezquitas y puertas de aparato. El contenido eminentemente coránico de las inscripciones monumentales almohades puede explicar el nuevo relieve otorgado a esta fórmula, cuyo uso en epigrafía no funeraria será mantenido, de manera casi sistemática, por meriníes y nazaríes ${ }^{68}$. Pero también aparece en la epigrafía funeraria de época almohade, bien como texto secundario ubicado en la orla (estela cordobesa del $587 \mathrm{H}$, ya citada), bien como inicio de las fórmulas introductorias previas al texto principal, sea éste el típico epitafio (mqābriyya de Fez), sea una cita coránica (mqābriyya de Játiva).

La basmala es de una gran fijeza, apareciendo en todos los casos en su versión completa: Bism Allāh al-Rahmān al-Rahìm, frente a la forma más escueta, Bism Allāh, en que se presenta en epígrafes fundacionales precedentes. La basmala reducida se incluía siempre en formularios de carácter propiciatorio a favor del soberano, que impusieron en las inscripciones fundacionales no religiosas los califas 'abbāsíes, fātimíes y omeyas de alAndalus ${ }^{69}$. La recuperación de la basmala completa viene a indicar también la renuncia expresa al formulario propiciatorio, apareciendo asimismo en las monedas almohades, frente a la versión escueta que presenta la mayor parte de las acuñaciones almorávides ${ }^{70}$.

La tașliya se incluye asimismo de manera sistemática bajo formas diversas, desde la más simple, șallà Allāh 'alà Muhammad (Bāb Agnaw, estela de la Cerca de Jerez y epígrafes funerarios), y otras con alguna ampliación, como șallà Allāh 'alà sayyidi-nā wa-mawlā-nā Muhammad wa-'alà àli-hi (puerta de la Qaṣbah de los Ūdāya) o șallà Allāh 'alà Muhammad waäli-hi wa-sallama tastiman (minbar de Fez), hasta las profusas tașliya/s declamatorias ${ }^{71}$ de los mihrāb/s de Marrakech, en las cuales se amplía la fórmula en todos sus extremos y se menciona a Muhammad como sayyidu-nā, mawlā-nā, al-nabì, al-muștafà y al-karim.

\footnotetext{
${ }^{68}$ Sobre los epígrafes meriníes, cfr. el trabajo de Aouni Lhaj Moussa, Etude des inscriptions merinides de Fas, tesis de doctorado inédita, dirigida por S. Orly y presentada en la Universidad de Provence en 1991. He de agradecer sinceramente a M. Aouni su amabilidad al regalarme un ejemplar de su valioso trabajo. Acerca de la epigrafía nazarí, puede consultarse: Lafuente y Alcántara, E., Inscripciones árabes de Granada, precedidas de una reseña histórica y de la genealogía detallada de los reyes alahmares, Madrid, 1860.

${ }^{69}$ Martínez Núñez, La epigrafía del Salón de 'Abd al-Rahmān III, p. 139.

${ }^{70}$ Medina Gómez, A., Monedas hispano-musulmanas. Manual de lectura y clasificación, Toledo, 1992, 393-43, para los almohades, y Kassis, H., «Notas históricas sobre las monedas de los almorávides», I Jarique de Estudios Numismáticos Hispano-Árabes, pp. 55-56.

${ }^{71}$ Deverdun, Inscriptions arabes de Marrakech, 14 y 53.
} 
El uso sistemático de la tașliya, junto a la variante declamatoria de las mezquitas, indica el enorme relieve que otorgaron los almohades a la misión profética, lo que se confirma también por el contenido de la fórmula final que presentan algunos epígrafes. Dicha fórmula final, șadaqa Allāh al'ažim (Q. III, 89), utilizada con anterioridad en los epígrafes funerarios almorávides ${ }^{72}$, es ampliada por los almohades con la mención del Profeta șadaqa Allāh (al-'až̀im) wa-rasūlu-hu (al-karìm) - y utilizada como colofón tanto en las inscripciones de los mihrāa/s, como en algunos epígrafes funerarios.

Pero si las fórmulas mencionadas muestran ciertos aspectos de la nueva orientación almohade, las citas coránicas constituyen los elementos centrales y más significativos del formulario, por diversas razones: en primer lugar, por lo que se podría denominar «adecuación» del texto coránico al soporte y al lugar en los que se ubica, así como a la función simbólica que se les asigna, y en segundo lugar, por remitir a los principios fundamentales del movimiento almohade.

Así, el texto coránico de los mihrāb/s de Marrakech pertenece a la sūra XXII, aleyas 76-77, usado frecuentemente en los epígrafes de las mezquitas del Oriente islámico ${ }^{73}$. La relación de ese texto coránico con el masŷid es

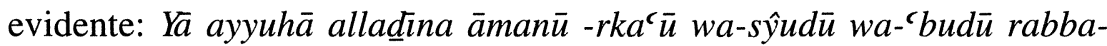
kum... («¡Oh, los que creéis! ¡Inclinaos! ¡Postraos! ¡Adorad a vuestro Señor!...»). Pero es interesante señalar que en las mezquitas yemeníes sólo se incluye el versículo 76, mientras que los almohades amplían la cita con

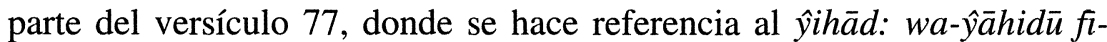
llāh haqq ŷihädi-hi, completado en el mihrāb de la Qașbah con: huwa iŷtabā-kum wa-mā $\hat{y} a^{\prime}$ ala 'alay-kum fi l-dìn min al-harây ( ${ }_{i}$ Combatid por Dios como se le debe! El os ha escogido. No os ha puesto dificultad en la religión»); texto más rotundo y expresivo, que siguieron utilizando después los meriníes $^{74}$

Otro tanto se podría decir sobre las citas coránicas de los frisos de la Bāb Agnaw y de la puerta de la Qaṣbah de los Ūdāya. En la Bāb Agnaw consiste en la sūra XV, 46-48: Udjulū (udjulū-hā en Corán) bi-salām āminīn / wanaza'nā mā fi șudūri-him min gill ijwānan'alà surur mutaqābilin / lā ya-

\footnotetext{
${ }^{72}$ Como en la estela cordobesa de arco de herradura que se conserva en el Museo de Málaga, del año 496/1103, que incluye al final de la orla șadaqa Allāh; cfr. Acien Almansa y Martínez Núñez, Catálogo de las inscripciones árabes del Museo de Málaga, núm. 14, lám. XIV.

${ }^{73}$ Cfr. Coussonet y Ory, Les inscriptions de la mosquée de Di Bin au Yémen, pp. 59-60.

${ }^{74}$ Como se observa, por ejemplo, en las inscripciones de la madrasa al-Sahrîy de Fez, recogidas por Aouni Lhaj Moussa, Etude des inscriptions merinides..., p. 63.
} 
massu-hum fi-hā nașab wa-mā hum min-hā bi-mujriŷ̃n («Entrad en paz, seguros / Habremos arrancado el odio que haya podido haber en sus pechos / No les tocará pena alguna, ni de los jardines serán expulsados»), referida al paraíso, con sus fuentes y jardines (Q. XV, 45), al que entrarán los creyentes, tras haber arrancado «el odio que haya podido haber en sus pechos». En la puerta de la Qașbah de los Ūdāya, el texto coránico elegido es la sūra LXI, 11-13, de un contenido similar a la anterior (aleya, 12): wa-yudjil-kum ŷannāt taŷrì min tahti-hā al-anhār wa-masākin țayyiba fi yannāt 'adn d̄ālika alfawz al-'azìm ( «Y (Dios) os introducirá en unos jardines por los que corren los ríos, y en excelentes moradas en los jardines del Edén es el mejor éxito»). En ambos casos queda patente la mención de la entrada al paraíso —en referencia a sendas puertas - y lo que es más importante, la capital Marrakech y las construcciones de la Qaṣbah almohade son representadas simbólicamente por el paraíso, con sus moradas y jardines; representación muy habitual en el urbanismo islámico ${ }^{75}$.

En la inscripción de la puerta de los Ūdāya la referencia al paraíso va precedida de la aleya anterior (Q, LXI, 11), en la que se lee: tu'minūna bi-llāh wa-rasūli-hi wa-tuŷāhidūna fi sabīl Allāh bi-amwāli-kum wa-anfusi-kum dālika jayr la-kum in kuntum ta 'lamūna / yagfir la-kum dunūba-kum wa-yudjil-kum... ( $\ll$ iCreed en Dios y en su Enviado! ¡Combatid en la senda de Dios con vuestros bienes y vuestras personas! Esto es lo mejor para vosotros, si vosotros sabéis, / (Dios) os perdonará vuestros pecados y os introducirá...»); una nueva mención del yihāad, más explícita que la precedente, de la cual se desprende que entrarán o serán introducidos en el paraíso, ese «paraíso» almohade, los creyentes que combaten en la senda de Dios con todos sus medios, los muŷāhidūn fi sabìl Allāh. Esa designación se proyectó en el laqab adoptado por uno de los califas almohades ${ }^{76}$. La aleya 13 de la misma süra, con la que concluye esta inscripción, añade otro elemento fundamental: el «auxilio de Dios», nașr min Allāh, y la «victoria inmediata», fath qarīb, para los muŷāhidūn que aman la otra vida, wa-ujrà tuhibbūna, con repercusión también en los laqab/s califales y en los formularios de la correspondencia oficial ${ }^{77}$.

${ }^{75}$ Cfr. Acién Almansa, M., «Madinat al-Zahrā en el urbanismo musulmán», Cuadernos de Madinat al-Zahrā, 1 (1987), 12-15; Jiménez Martín, A., « Los jardines de Mađinat al-Zahrā'», Cuadernos de Madihat al-Zahrā', 1 (1987), 82-84.

${ }^{76}$ Concretamente el califa Idrīs al-Ma'mūn, quien aparece en las leyendas de las doblas como al-Muŷāhid y al-Muŷāhid fi sab̄ll Allāh, cfr. Prieto y Vives, La reforma numismática de los almohades, núms. 13, 14 y 15. Esta designación la usarían frecuentemente los sultanes nazaríes y meriníes.

77 El califa Abū Yūsuf Ya'qūb, cuyo laqab habitual era al-Manșūr, aparece designado a veces en la correspondencia oficial como al-Nāṣir li dìn Allāh y Näșir al-dìn; con este último tam- 
Sin embargo, la cita coránica más rotunda, por su contenido y significado, es la que se incluye, no por azar, en el friso de la Bāb al-Ruwāh, la puerta de mayor importancia de la muralla de Ribāt al-Fath, ciudad de fundación almohade. Por los datos de que dispongo, es la única vez que en epigrafía almohade, y árabe en general, se incluyen las aleyas 106-107 de la süra III: kuntum jayr umma ujriŷat li-l-nās ta'murūna bi-l-ma'rūf wa-tanhawna 'an al-munkar wa-tu'minūna bi-llāh wa-law àmana ahl al-kitāb la-kāna jayran lahum min-hum al-mu'min̄̄n wa-aktaru-hum al-fāsiqūn / lan yadurru-kum illā aḍà wa-in yuqātilū-kum yuwallū-kum al-adbār țumma lā yunșarūna («Sois la mejor comunidad que se ha hecho surgir para los hombres: ordenáis lo establecido y prohibís lo reprobable y creéis en Dios. Si la gente del libro hubiera creído, hubiese sido mejor para ellos. Entre ellos hay creyentes, pero en su mayoría son perversos. / No os causarán daño, sino molestia, si os combaten os volverán la espalda, a continuación no serán socorridos»).

Aquí no se trata, como en los casos anteriores, de la relación simbólica con el lugar de ubicación del epígrafe y su función, sino de la mención expresa de las bases éticas y religiosas que sirvieron de legitimación al movimiento almohade y a la dinastía mu'miní, acompañada de una aleya de recriminación referida a las gentes del libro, a los judíos de Medina.

En efecto, de la süra III, en la que se ensalza a la comunidad de creyentes frente a judíos y cristianos, fueron escogidas para la inscripción de la Bāb al-Ruwāh precisamente las aleyas 106-107, las cuales, junto al versículo 110 de la misma süra, dieron origen al conocido deber ético islámico de $a l$ amr bi-l-ma'rüf wa-l-nahy 'an al-munkar, denominado también con un término no coránico: hisba ${ }^{78}$.

Este deber de vigilancia y censura de costumbres, que incumbe a todo musulmán, y su operatividad como instrumento político en el Magreb a partir del siglo XII, ha sido ampliamente tratado por algunos investigadores, especialmente en su relación con el desarrollo de los movimientos sufíes ${ }^{79}$. También es suficientemente conocida, en este mismo sentido, la in-

\footnotetext{
bién el califa al-`Ādil; cfr. Azzaoui, A., Rasā'il muwahhidiyya. Maŷmū'a ŷadida, tomo I, Kenitra, 1995, p. 554, carta del 593-4 H., y p. 571, carta del 624 H. El cuarto califa ostentó el de al-Nāsir y los meriníes usaron habitualmente estos sobrenombres honoríficos, muy tradicionales en la historia de la institución califal. Con respecto a las fórmulas iniciales de la correspondencia oficial, era habitual, ya desde 'Abd al-Mu'min, la expresión Ayyada-hu Allāh bi-nașrihi; ibidem, p. 542, carta del 555 H., y p. 544, del año $561 \mathrm{H}$.

${ }^{78}$ Cahen, C., y Talbi, M., Hisba, EI , III (1971), pp. 503-505.

${ }^{79}$ Cfr. especialmente García Arenal, M., «La práctica del precepto de al-amr bi-l-ma' rüf wal-nahy 'an al-munkar en la hagiografía magrebí», Al-Qanțara, XIII (1992), 143-165, y Ferhat, H., «Souverains, saints et fuqahä': le pouvoir en question», Al-Qanțara, XVII (1996), 375-390.
} 
fluencia del Ihyya $\bar{a}$ de al-GazāTi en todos los movimientos antialmorávides que usaron como bandera de su oposición política el principio de hisba, y especialmente en el iniciado por Ibn Tümart ${ }^{80}$, el único que finalmente triunfó y se hizo con el poder. Por ello, sólo deseo recordar aquí el carácter subversivo que adquiere este deber de censura de costumbres cuando se usa como arma política o como argumento para deslegitimar al poder establecido —es lo que consiguió Ibn Tümart al esgrimirlo frente a los almorávides-y la necesidad subsiguiente de los califas mu'miníes de asumirlo como lema propio para neutralizar su efectividad ${ }^{81}$.

También es preciso señalar, como hace M. García Arenal ${ }^{82}$, que quien practica la hisba se presenta como Mahdi, reformador por antonomasia, guiado por Dios para corregir la injusticia y la corrupción de los gobernantes y para encabezar a la comunidad, y consecuentemente como Imām, que ha de ser obedecido en todo. El ejemplo paradigmático de ese proceder es, sin duda, el del Mahdī Ibn Tümart, que se proclamó Imām ma'șüm; es decir, que reclamó también la 'ișma («exención del error y del pecado»), de fuerte raigambre $S_{i} \iota^{(} i$ y que se atribuye a los imames y a los profetas ${ }^{83}$.

Pues bien, la utilización de esas aleyas coránicas en la Bāb al-Ruwāḥ indica el deseo de los califas almohades de vincularse teóricamente con el Mahdi, con el pilar fundamental de la ideología y de la actuación de Ibn Tümart, pero sobre todo demuestra la necesidad perentoria que tuvieron de controlar directamente la hisba, de convertirse en los primeros censores de costumbres y de utilizar dicho principio como elemento propagandístico. Ambos aspectos se ven ampliamente corroborados por otras fuentes escritas. La vinculación con el Mahdī se recoge en las crónicas, cuando insisten, por ejemplo, en la designación directa de 'Abd al-Mu'min por Ibn Tümart ${ }^{84}, \mathrm{y}$ en las monedas, cuyas leyendas incluyen siempre su mención. La asunción oficial del deber de hisba se observa no sólo en las cartas oficiales que los

\footnotetext{
${ }^{80}$ García Arenal, «La práctica del precepto...», pp. 151-156; Guichard, Les Etats musulmans du Maghreb, p. 187.

${ }^{81}$ Sobre la asunción de la hisba por el poder califal para neutralizar su capacidad de subversión; cfr. Gardet, L., La cité musulmane, vie sociale et politique, Paris, 1954, 184-188, y García Arenal, «La práctica del precepto...» p. 157.

82 Ibidem, pp. 157 y 162.

${ }^{83}$ Madelung, W., 'Isma, EI , IV (1978), pp. 190-192; del mismo autor, Imāma, El 2, III (1971), 1192-1198; Sourdel, D., Khalifa, ER , IV (1978), pp. 976; Lévi Provençal, Documents inédits, 24 y 120.

${ }^{84}$ Lévi-Provençal, Documents inédits, p. 34; Huici, A., «La leyenda y la historia en los orígenes del imperio almohade», Al-Andalus, XIV (1949), 342-350 y 367-368.
} 
califas dirigían a los țalaba y a la comunidad ${ }^{85}$, sino en la organización dentro de la estructura del sistema almohade de un cuerpo de muhtasib/s ${ }^{86}$.

Lo importante es que con esta asunción, que los vinculaba al Mahdi, los mu’miníes sentaban las bases para legitimar su adopción del título califal eran califas legítimos por ser continuadores de la reforma del Imām $m a^{\top}$ șüm - y así estos Kumya contrarrestaban las aspiraciones al poder de los clanes almohades del Atlas, que extraían su prestigio de la antigüedad de su adhesión a Ibn Tümart.

En relación con lo anterior, resulta evidente, como ya he mencionado acerca de las citas coránicas, el gran relieve que adquiere en la epigrafía almohade el Profeta Muḥammad y su misión, corroborado por la inclusión sistemática en las leyendas de las monedas de la sahāda y de las expresiones Allāh rabbu-nā, Muhammad rasülu-nā, seguidas siempre de la mención del Mahdì ${ }^{87}$ : al-Mahdì imām al-umma, al-Mahdì jalifat Alläh ${ }^{88} \mathrm{o}$ al-Mahdì imāmu-nāa. El lugar destacado de la misión del Profeta en epigrafía y la mención del Mahdi, tras la de Muhammad, en las monedas constituyen otra prueba del intento de adjudicar a Ibn Tümart y a 'Abd al-Mu’min una genealogía idrīsī y sarīifi ${ }^{89}$, con el objetivo de legitimar también por esta vía la adopción del título califal. Pero, asimismo, debe responder a la conocida equiparación que pretendieron establecer entre el Profeta y el Mahdi (imām $m a^{\top} s \bar{u}_{m} m$ y jalifat Allāh), entre la primitiva comunidad islámica y la restauración almohade ${ }^{90} \mathrm{y}$, por consiguiente, entre los califas rāsidūn y los mu'miníes. En ese sentido no deja de ser significativo el hecho de que los califas Yūsuf II al-Mustanșir y Yahyà al-Mu'tașim sean mencionados en los dinares como ibn al-julafă ${ }^{3}$ al-rāsidìn ${ }^{91}$, y siendo Yūsuf al-Mustanșir el quinto califa mu’miní, la equiparación no puede ser más clara.

En definitiva, la fuente primera de legitimación del califato dinástico mu’miní era el presentarse como sucesor del Mahdī, con las connotaciones

${ }^{85}$ Lévi-Provençal, Documents inédits, pp. 21-24, carta de 'Abd al-Mu'min del $556 \mathrm{H}$.; Azzaoui, Rasā'il muwahhidiyya, p. 572, carta de al-Ma'mūn del $624 \mathrm{H}$.

${ }^{86}$ Lévi-Provençal, Documents inédits, pp. 70-71.

${ }^{87}$ Salvo en las acuñaciones de plata del califa al-Ma'mūn, quien renegó de la doctrina de Ibn Tümart, donde la mención del Mahdi es sustituida por las expresiones al-Qur'ān imāmu-nă y al-Qur'ān huŷŷyat Allāh; cfr. Fontenla Ballesta, «La numismática almohade», p. 69, y en una dobla de su sucesor al-Rasìd, Prieto y Vives, La reforma numismática de los almohades, p. 29.

${ }^{88}$ Sourdel, Khalifa, p. 971, sobre jalifat Allāh, frente a jalifat rasül Allāh.

${ }^{89}$ Lévi-Provençal, Documents inédits, pp. 19,30 y 32.

${ }^{90}$ Huici, «La leyenda y la historia en los orígenes del imperio almohade», p. 368; Ferhat, Le Maghreb au XII et XIII siècles, p. 101.

${ }^{91}$ Prieto y Vives, La reforma numismática de los almohades, 27 y 28. 
mencionadas, y como continuadores de su misión, asumiendo desde el poder los principios éticos e ideológicos de su reforma con el fin último de controlarlos o neutralizarlos, pues nadie mejor que ellos mismos podía conocer su capacidad de desestabilización.

Y este hecho da sentido al carácter del formulario y del léxico usados en la epigrafía oficial. La relación estrecha que se establece entre hisba y $\hat{y} i h \bar{a} d^{92}$ —este último en el sentido del «esfuerzo», del combate, que ha de llevar a cabo todo musulmán por cumplir y hacer cumplir lo establecido, empleando incluso la fuerza- explica la inclusión en los epígrafes oficiales de los textos coránicos alusivos al yihäd fi sabill Alläh, los cuales muestran al mismo tiempo la neutralización de ese deber individual, al ser asumido igualmente por los califas almohades. Si desde los orígenes de la institución califal fueron acaparados ambos principios éticos por el poder, ahora tiene lugar una auténtica manipulación política de los mismos.

También en nombre de la hisba y el yiha àd se entiende el hecho de que incluyeran en la escritura propagandística la censura a las gentes del libro, a través del pasaje coránico con el que concluye la inscripción de la Bāb alRuwāh, un texto donde se ensalza a los pocos que creen en las aleyas de Dios, pero se ataca a los perversos. En ese sentido no se debe olvidar que la reforma religiosa de Ibn Tümart terminaría para los judíos con la supresión de la dimma y que, precisamente en tiempos de Ya'qūb al-Manșūr, el poder almohade estaba tan poco seguro de la sinceridad de los neomusulmanes que impuso a los judíos llevar un distintivo para materializar su condición ${ }^{93}$. Tampoco ha de olvidarse el ŷihād llevado a cabo por los soberanos almohades contra los reinos cristianos de al-Andalus y contra todos aquellos que no les reconocían como tales ${ }^{94}$, ni la organización por Ya'qūb al-Manșūr de un cuerpo de guzāt, combatientes por la fe, incluidos entre los muhtasib/s ${ }^{95}$.

El control ejercido por el poder sobre los deberes de hisba y $\hat{y} i h \bar{a} d$ da sentido también a la inclusión en las escrituras propagandísticas de citas coránicas y de términos relativos al «auxilio» (nașr), la «asistencia» (tawfiq), la «gracia» (ni`ma), la «prosperidad» (gibta), la «bendición» (baraka), la «felicidad» (yumn), el «poder (mulk y amr), la «fuerza» (quwwa) o la «vic-

92 García Arenal, «La práctica del precepto...», 155 y 163.

${ }_{93}$ Levy, S., «Messianisme, Mahdi et crise almohade», Mahdisme, crise et changement dans l'histoire du Maroc (Table Ronde), Rabat, 1994, p. 36.

${ }_{94}$ Ferhat, Le Maghreb au XII et XIII siècles, p. 102; Guichard, Les Etats musulmans du Maghreb, pp. 187-189.

${ }_{95}$ Lévi-Provençal, Documents inédits, 70. En época meriní se mantendrán los guzāt y una siyājat al-guzāat para el ŷihād en territorio andalusí. 
toria» (fath), todos ellos emanados de Dios, y a la alabanza, la glorificación y el agradecimiento a Dios: subhān, hamd, 'izza, sukr. Dios concede su auxilio y su asistencia, pero también el poder, la fuerza y la victoria, cuando se garantiza la hisba y el $\hat{y} i h a \bar{d}$, y ello origina la alabanza y el agradecimiento a Dios ${ }^{96}$.

Se trata de un léxico extraído del corpus sagrado, de gran fijeza y uniformidad, y que cuenta con la particularidad en época almohade de formar parte de las denominadas «eulogias en Allāh», o «eulogias de Allāh», frente a lo que sucedía en etapas precedentes cuando dichas eulogias estaban destinadas a pedir explícitamente la bendición y el auxilio divino para el soberano, función propiciatoria que retomarán más tarde los meriníes y los nazaríes. Y es que, como acertadamente ha señalado S. Gubert ${ }^{97}$, frente a la apariencia de perennidad de este léxico, tradicionalmente utilizado en epigrafía islámica, en momentos y contextos determinados puede adquirir una carga semántica y un valor simbólico específicos.

Sin duda alguna, el uso exclusivo de este tipo de eulogias es un nuevo indicador de la utilización por parte de los mu’miníes de otra de las claves de la reforma de Ibn Tümart: la restauración de la absoluta unidad de Allāh y de todos sus atributos, frente a las desviaciones que el Mahdi atribuía a los almorávides, acusándoles de «antropomorfistas» ${ }^{98}$. La mejor prueba la proporciona el lema almohade, al-hamdu li-llāh wahdu-hu, uno de los motivos tipo de la mezquita de Tinmal, usado como 'aläma en la correspondencia oficial ${ }^{99} \mathrm{y}$ en las leyendas de los dinares a partir del califa Ya'qūb alManșūr.

Entre las eulogias que contienen los motivos tipo de Tinmal se encuentran, junto a la sahāda y la hamdala, frases dedicadas al Dios único: subhān Allāh y al-mulk li-llāh wahdu-hu, y en los de la puerta de la Qaṣbah de los Ūdāya: al-mulk li-llāh wahdu-hu, al-sukr li-llāh waḥdu-hu y la significativa Allah' ‘udda li-kull sidda (lám. 4, fig. 3). En las monedas figuran, junto a la sahāda citas coránicas que aluden a la unidad y al favor divino: wa-ilāhukum ilāh wāhid lā ilāh illā Allāh (Q. II, 158), wa-mā bi-kum min ni ‘ma fa-min Allāh (Q. XVI, 55), wa-mā tawfiqù illā bi-llāh (Q. XI, 90), al-amr kullu-hu lillāh (Q. III, 148) o lā quwwa illā bi -llāh (Q. XVIII, 37); eulogias y citas que

${ }^{96}$ Cfr. Gubert, «Povoir sacré et pensée mystique...», p. 413, sobre el léxico usado por los meriníes.

97 Ibidem, p. 393

${ }_{98}$ Lévi-Provençal, Documents inédits, pp. 1-12 y 13-15, cartas del Mahdĩ a los almohades.

99 Azzoui, Rasā'il muwahhidiyya, p. 61, nota 4 y p. 69, sobre el uso de la 'aläma desde 'Abd al-Mu'min. 
fueron integradas y adoptadas por los sultanes meriníes en sus formularios numismáticos y epigráficos ${ }^{100}$.

Pues bien, estas eulogias y este léxico, utilizados para proyectar la imagen que el poder deseaba dar de sí mismo, fueron empleados en diversos materiales: piedra, yeso, madera, metal, cerámica, y en todo tipo de soportes: $m i h r a \bar{b} b / \mathrm{s}$, alminares, almimbares, puertas monumentales, brocales de pozo, estelas funerarias, pero también en la cerámica de uso doméstico. Ya para terminar, quiero referirme brevemente a esta última como una prueba más de la diversificación de los medios de propaganda almohade.

Entre los abundantes restos cerámicos de cronología almohade, procedentes de diversas zonas de al-Andalus, destaca por su uniformidad la cerámica vidriada en verde, total o parcialmente, con decoración estampillada y breves epígrafes en cúfico y cursiva. Estas cerámicas, generalmente recipientes de gran capacidad (tinajas), que se generalizan a partir del siglo XII, reproducen en sus epígrafes el mismo léxico de alabanza a Dios, de favor divino y de agradecimiento que las escrituras oficiales almohades, como se desprende del abundante lote, todo él de cronología almohade, de Mértola ${ }^{101}$, y de los procedentes de otras ciudades de al-Andalus ${ }^{102}$. Entre ese léxico fijo es significativo el uso del término al-tawfiq («la asistencia» divina), considerado «ilegible» en una ocasión y leído erróneamente en otra ${ }^{103}$. El mismo término se incluye en las leyendas de los dinares y no creo que sea fruto del azar el que en las cartas dirigidas por el Mahdī a los almohades aparezca siempre y repetidamente la expresión: wa-'lamī waffaqa-kum Allāh... ${ }^{104}$ La uniformidad de las técnicas decorativas y del léxico empleado, frente a la diversidad de los lugares de hallazgo, indica la existencia de escasos centros productores desde los cuales se difundía este tipo de cerámica, cuyo uso hubo de estar asociado a la implantación y reconocimiento del dominio almohade.

${ }^{100}$ Gubert, «Pourvoir sacré et pensée mystique...» pp. 398, 408-410; Medina Gómez, Monedas hispano-musulmanas, pp. 498-529.

${ }^{101}$ Khawli, A., «Lote de cerámica epigrafiada em estampilhagem de Mértola», Arqueología Medieval, 1 (1992), 7-25.

${ }^{102}$ Garrido Garrido, M., y García Granado, J. A., «Introducción al estudio de la cerámica andalusí en Granada», II Congreso de Arqueología Medieval Española, 19-24 de enero de 1987; II Comunicaciones, Madrid, 1987, 678-687; Aguado Villalba, J., Tinajas medievales españolas islámicas y mudéjares, Madrid, 1991, 42-43, 78-80, 97-108; Torremocha Silva, A., «Cerámica estampillada del Museo Municipal de Algeciras», Caetaria, 1 (noviembre, 1996), 93-100.

${ }^{103}$ Khawli, «Lote de cerâmica...», núms. 53 y 54; Torremocha Silva, «Cerámica estampillada...», núm. 11, donde se lee li-l-haqq fa-la-hu.

${ }^{104}$ Lévi-Provençal, Documents inédits, pp. 3-9 del texto árabe. 


\section{RESUMEN}

En el presente artículo se analizan las características de la epigrafía oficial almohade de Marruecos, en tanto que elemento de gran importancia dentro del sistema propagandístico diseñado por la dinastía mu'miní. El estudio se centra en los rasgos caligráficos y en el contenido textual de las inscripciones oficiales, así como en la difusión y la influencia de los mismos en la epigrafía del Magreb y de al-Andalus desde finales del siglo XII.

\section{ABSTRACT}

This article analyses the characteristics of Almohad official epigraphy from Morocco in order to establish some of the elements of the propaganda system devised by the Mu'minid dynasty. The analysis focuses on the calligraphic features and the textual content of the official inscriptions and their diffusion in the Maghrib and al-Andalus since the end of the 12 th century. 